\title{
Strategic intent of OBOR: enhancing energy supply resilience
}

\author{
Loon Ching Tang ${ }^{1}$ and Joyce M.W. Low ${ }^{2^{*}}$
}

\author{
* Correspondence: joycelow@smu. \\ edu.sg \\ ${ }^{2}$ Singapore Management University, \\ Lee Kong Chian Business School, 50 \\ Stamford Road, \#05-01 Singapore \\ 178899, Singapore \\ Full list of author information is \\ available at the end of the article
}

\begin{abstract}
Since the launch of the One Belt, One Road (OBOR) initiative in 2015, China has announced its intention to invest in major infrastructure projects to promote trade and co-operation with its trading partners along OBOR. This paper examines the current level of trading and key projects underway along OBOR so as to provide insights to understand its strategic intent. In particular, a network model is constructed to analyze the impact to China current and future demand for energy under various conditions especially during prolonged periods of supply uncertainties. Since these key projects are closely connected to the current and proven oil and natural gas reserves locations, the findings propound the OBOR initiative is more than trade and a key motivation is to enhance China's energy supply resilience amongst other imperatives.

Keywords: OBOR, Belt road initiative, Intermodal network, Energy resilience, Oil, Malacca's Trap
\end{abstract}

\section{Introduction}

On March 28th, 2015, the "Vision and Actions on Jointly Building Silk Road Economic Belt and 21st-Century Maritime Silk Road" was issued by the National Development and Reform Commission, Ministry of Foreign Affairs, and Ministry of Commerce of the People's Republic of China, with State Council authorization. Stated in the document, "The initiative is an ambitious economic vision of the opening-up of and cooperation among the countries along the Belt and Road. Countries should work in concert and move towards the objectives of mutual benefit and common security. To be specific, they need to improve the region's infrastructure, and put in place a secure and efficient network of land, sea and air passages, lifting their connectivity to a higher level; further enhance trade and investment facilitation, establish a network of free trade areas that meet high standards, maintain closer economic ties, and deepen political trust; enhance cultural exchanges; encourage different civilizations to learn from each other and flourish together; and promote mutual understanding, peace and friendship among people of all countries" (National Development and Reform Commission, Ministry of Foreign Affairs, and Ministry of Commerce of the People's Republic of China, with State Council authorization, 2015).

This initiative is commonly known as One Belt, One Road (OBOR) or Belt and Road Initiative (BRI) and five key areas of cooperation including policy coordination, facilities connectivity, trade, financial integration and people to people ties have been

(c) The Author(s). 2020 Open Access This article is distributed under the terms of the Creative Commons Attribution 4.0 International License (http://creativecommons.org/licenses/by/4.0/), which permits unrestricted use, distribution, and reproduction in any medium, provided you give appropriate credit to the original author(s) and the source, provide a link to the Creative Commons license, and indicate if changes were made. 
identified. At the inaugural Belt and Road Forum held from 14 to 15 May 2017, China announced it will inject at least RMB780 billion (US\$113 billion) via its state funds and banks into infrastructure projects under the Belt and Road Initiative. In South East Asia, more than US\$ 80 billion potential project value was committed in the Philippines, Indonesia and Malaysia in the telecommunication, transport \& energy infrastructure, manufacturing and agriculture sectors (Chan, 2017). Some of these potential infrastructure developments are shown in Fig. 1.

Cheng (2016) summarized the possible real objectives behind the OBOR initiative as (i) to conquer world markets by opening up the markets of emerging and developing economies; (ii) to secure supply of resources, especially in the natural resource sector, by making direct investment; (iii) to extend the country's global strategy of promoting Renminbi's (RMB) internationalization by using RMB as well as part of an excessive foreign reserves; (iv) to strengthen the diplomatic relationship between China and the partner countries; and (v) to counter the economic aspects of the U.S. strategic "Pivot to Asia" policy, which includes the Trans-Pacific Partnership (TPP) free-trade agreement that appears to explicitly and intentionally exclude China's participation.

While OBOR aims to boost trade by providing connectivity along two routes, one following the ancient Silk Road from China through central Asia and the Middle East to Europe and the other linking China to South East Asia and East Africa, with or without the OBOR, China is already one of the worlds' largest trading partners for most countries. In the first half of 2015, the gross exports and imports between China and countries along the Belt and Road totaled US $\$ 485.4$ billion, or $26 \%$ of the gross value of foreign trade, and China's outward foreign direct investment in 48 roadside countries amounted to US\$7.05b, or $15.3 \%$ of total investments, up $22 \%$ year on year (EY, 2015). It has been estimated that China's trade value with OBOR countries reached US \$ 953 billion in 2016, or 25.7\% of China's total trade and Memorandum of Understanding have been signed with countries such as Pakistan, Malaysia, Philippines, Bangladesh, Russia, Kazakhstan, Saudi Arabia, Serbia and Ethiopia amounting to some US \$ 274 billion (Chua, 2017). Foreign trade is one of the major pillars underpinning China's phenomenal economic growth over the past three decades, and oil is intimately related to it (Zhang, 2011).

China consumes close to 600 million tons of oil in 2016 and is a net importer of oil since 1993. Its foreign oil dependency ratio hits $65 \%$ in 2016 and this may climb further if no preventive measures are adopted (BP, 2017). Between 1995 and 2016, the

Three key land routes via Silk Road Economic Belt

- China-Central Asia-Russia-Europe

- China-Central Asia-Middle East

- China-Southeast Asia-South Asia-Indian Ocean

Two main ocean routes via the 21 st Century Maritime Silk Road

- China - South China Sea - Indian Ocean Europe

Potential infrastructure developments including road, rail and power projects

- New Eurasian Land Bridge

- China Mongolia Russia Corridor

- China Central Asia West Asia Corridor

- China Pakistan Economic Corridor (CPEC)

- China Bangladesh India Myanmar Corridor

China Coastal Ports - South China Sea -

South Pacific Ocean

Fig. 1 Potential infrastructure developments along One Belt, One Road 
transport, storage and post sector have the highest energy consumption compound annual growth rate (CAGR) of more than $10 \%$ (Table 1). He et al. (2005) cautioned China's road transportation will gradually become the largest oil consumer and the annual oil demand for China's road vehicles may reach 363 million tons by 2030. This amounts to more than $60 \%$ of 580 million tons of oil consumed in 2016 .

According to Zhang (2011), China relied on the Middle East and the Southeast Asia (mainly Indonesia, which alone accounted for nearly one-third of China's total imports) for $82 \%$ of its crude oil imports in 1995. By 2005, China had significantly diversified its import mix through energy deals with oil-rich African countries in the Gulf of Guinea, Central African Republic, Chad, Congo, Libya, Niger, and Sudan. Specifically, Africa accounted for $30 \%$ of China's oil imports, while Russia supplied $10 \%$ of the total imports (Downs, 2006:31). Nonetheless, China remained just as reliant on the Middle East in 2005 as it had been 10 years ago, with $47 \%$ of its imports coming from the Persian Gulf. As of 2010, 77\% of China's crude oil imports is from the Middle East and Africa (Kennedy, 2011). Liu (2016) observed that there are many major oil-producing countries along the OBOR and may thus be helpful towards China's effort on supply sources diversification.

Most of China's oil imports are transported by the sea and this raises another question of diversification of routes for China, in addition to that of supply. The fact that China was now heavily reliant on Africa, as well as, the Middle East means that it depends more on a single choke point-the Strait of Malacca-than it had been before, with nearly 77\% of its oil imports flowing through the Strait. Zhang (2011) cautioned that China will be even more exposed to the risk of international supply disruption than it is today. The challenge for China, thus, remains in combining diversification of imports with the minimization of risk that arises from the geopolitics of oil resources and supply routes to enhance China's energy supply resilience (Cao and Bluth, 2013). Resilience as defined in the US Presidential Policy Directive (PPD) 21 is "the ability to prepare for and adapt to changing conditions and withstand and recover rapidly from disruptions. Resilience includes the ability to withstand and recover from deliberate attacks, accidents, or naturally occurring threats or incidents" (SNL, 2015). Thus, the resilience of the inland or sea transport network, specifically towards a disruption scenario, is intuitively understood to be the ability of the network to fulfill its objective supplying goods from the coastal ports towards the inland cities to fulfill demands

Table 1 Energy consumption by sector

\begin{tabular}{llll}
\hline Sector & \multicolumn{2}{l}{10,000 tons of } & \multirow{2}{*}{ CAGR } \\
\cline { 2 - 3 } & \multicolumn{2}{l}{ Standard Coal Equivalent } \\
\cline { 2 - 3 } & 1995 & 2016 & \\
\hline Agriculture, Forestry, Animal Husbandry, Fishery and Water Conservancy & 5505 & 8544 & $2.41 \%$ \\
Industry & 96,191 & 290,255 & $5.92 \%$ \\
Construction & 1335 & 7991 & $10.24 \%$ \\
Transport, Storage and Post & 5863 & 39,651 & $11.18 \%$ \\
Wholesale and Retail Trades, Hotels and Catering Services & 2018 & 12,015 & $10.47 \%$ \\
Other Sectors & 4519 & 23,154 & $9.78 \%$ \\
Household Consumption & 15,745 & 54,208 & $7.27 \%$ \\
\hline
\end{tabular}

(Sources: China Statistical Yearbooks 1997 and 2018) 
despite components of the network being disrupted to minimize economic losses (Guo and Tang, 2014).

The OBOR initiative presents China an excellent opportunity to provide the needed resources including infrastructure to tap into existing and new oil and gas reserves. Out of a total of 29 oil resource-rich countries, 11 countries are along the twenty-firstCentury Maritime Silk Road and 5 countries are along the Silk Road Economic Belt (Liu et al., 2016). Table 2 shows that countries along OBOR account for more than $65 \%$ of the world's remaining proved and probable reserves and more than $55 \%$ of the world's total recoverable energy. Furthermore, it has also been estimated that OBOR member countries house $35.6 \%$ of the worldwide newly discovered oil resource and $67 \%$ of the worldwide newly discovered natural gas resource (Pan et al., 2016). Based on statistics and forecast provided by the International Energy Agency (IEA), US Energy Information Administration (EIA) and BP, countries along OBOR will account for more than $50 \%$ of global oil \& gas production in the next 20 years.

In terms of route diversification, the OBOR initiative offers several energy supply routes that circumvent the need to pass through the Straits of Malacca. More specifically, the Kazakhstan-China oil pipeline was completed in 2009 with a designed maximum capacity of 20 million tons per year (Wang and Zhao, 2014). The Russia-China oil and gas pipeline was built since 2011 and expanded in 2015 to handle a maximum capacity of 30 million tons per year. The Chinatrans-Myanmar oil and gas pipeline started operations in 2015 and provide an alternative supply route to import crude oil from the Middle East. Along the China-Pakistan Economic Corridor, a deep-sea Gwadar Port and railway is being is being built for shipping of oil from Middle East and Africa to avoid the Strait of Malacca or South China Sea. In addition, a study is being conducted to determine the feasibility of building the Kra Canal to avoid using Strait of Malacca for shipping of energy resources. Furthermore, to avoid the sea shipping completely, an energy bridge for oil and gas to link Middle East to Central Asia is also being considered. This energy bridge will route from Turkmenistan towards Uzbekistan and Kazakhstan for Horgos Port in China and Turkmenistan towards Iraq, Syria and the Saudi Arabia (Wang and Zhao, 2014).

As the energy-related projects along OBOR route are seemingly linked to the current and proven oil and natural gas reserves locations, such associations propound that the OBOR initiative is more than just to facilitate trade. Rather, the probable motivation is to enhance China's energy supply resilience amongst other imperatives. This paper examines the pipeline projects underway along OBOR so as to provide insights to understand its strategic intent of the OBOR initiative. An intermodal network model, consisting of 19 import (or supply) cities, 35 refinery plants and 9 consumption (or

Table 2 Energy reserves in countries along OBOR

\begin{tabular}{llll}
\hline Energy resource type & $\begin{array}{l}\text { Crude oil } \\
\text { (billion tons) }\end{array}$ & $\begin{array}{l}\text { Natural gas (trillion } \\
\text { meter cube) }\end{array}$ & $\begin{array}{l}\text { Oil equivalent } \\
\text { (billion tons) }\end{array}$ \\
\hline Accumulated production & 74.36 & 39.9 & 106.36 \\
Remained proved and probable reserve & 136.02 & 171.7 & 273.87 \\
\% of worldwide reserve & $71.90 \%$ & $67.60 \%$ & $67.93 \%$ \\
Total recoverable & 307.71 & 325.7 & 569.23 \\
\% of worldwide reserve & $56.30 \%$ & $58.20 \%$ & $56.15 \%$ \\
\hline
\end{tabular}

(Source: Pan et al., 2016) 
demand) cities, is constructed to analyze the impact on China's current and future demand for energy under various conditions especially during prolonged periods of supply uncertainties. The supply cities include 4 inland cities for which crude oil is imported via pipelines and 15 seaport cities. Of the 15 seaports, 8 receive crude oil on maritime routes going through the Straits of Malacca. Refinery plants are scattered across the entire country. Some of these are the existing plants running on old technologies, some are upgraded while others are newly constructed. A schematic of the imported oil to 15 seaports and 4 inland pipelines along OBOR leading to China is shown in Fig. 2. The network model is complemented by a goal programming model that determines the most economical transportation routes to satisfy the projected oil consumption demand at the major cities of China in 2023. The investment decisions into the existing and new refinery plants are then evaluated in the light of their estimated utilizations, arising from the flow volumes on the transportation routes. Subsequently, results identify important (alternative) sources of oil supplies should China be exposed to varying degrees of the Malacca Trap and the channels from which they will be imported.

The rest of the paper is organized in the following manner: Section 2 discusses the existing literature on oil supply routes into China. Section 3 constructs the network optimization model to study the impact on China's current and future demand for energy under various supply conditions. An experimental study is conducted to better

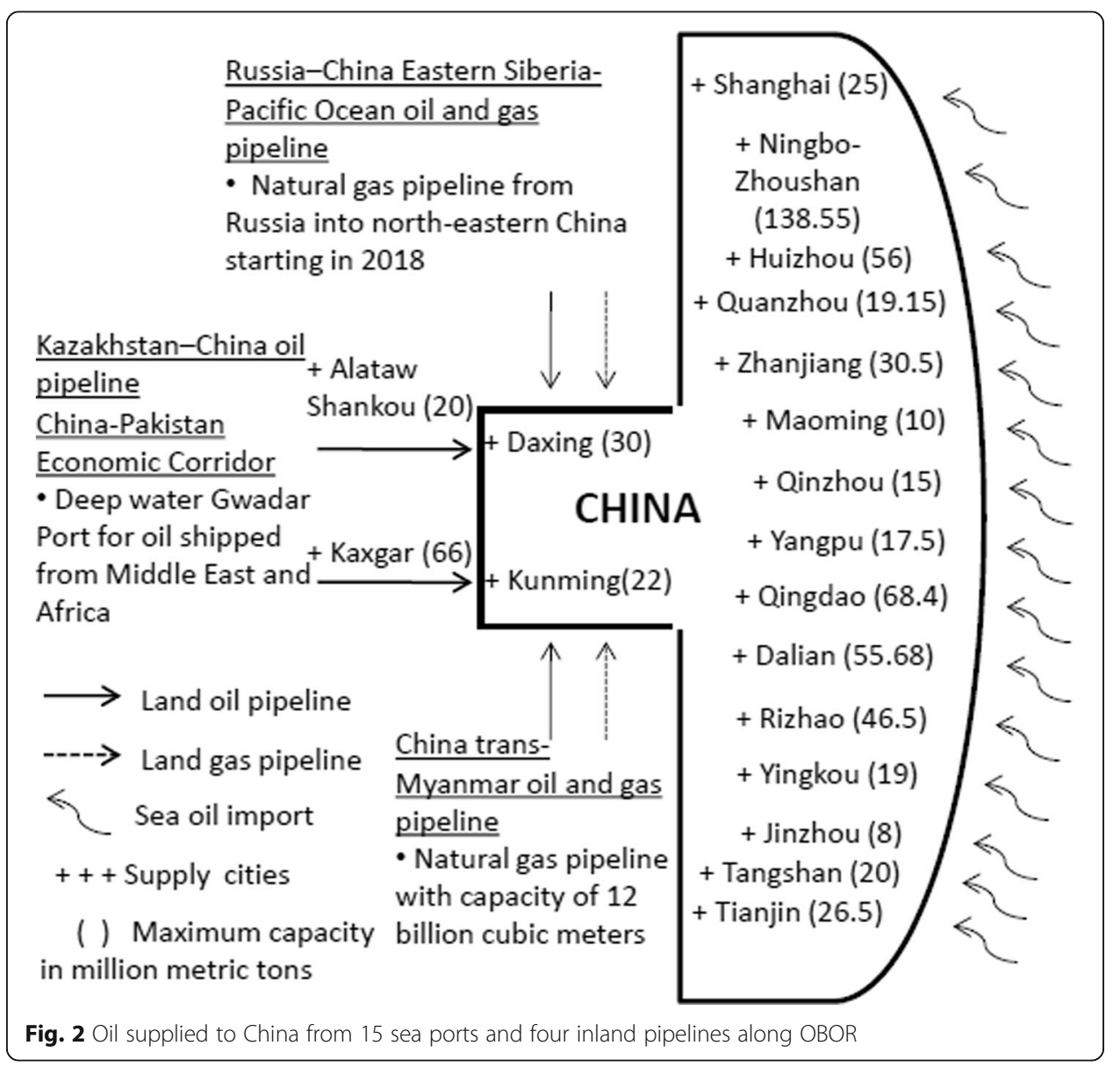


understand China's energy supply resilience in the face of major disruptions at the supply, intermediate and demand energy transportation nodes and to provide insights to the strategic intents for a large-scale initiative like OBOR. The analysis is conducted in two stages where Section 4 first presents the solutions generated by the model on optimal transportation flows of crude oil from the supply cities to the refineries before reaching the end cities where the refined oil is consumed. Given the planned capacities and projected demand volume, estimations on the amount of oil to be obtained from the different supply sources and utilizations of the refinery plants are made. A sensitivity analysis is also being carried out to better understand cost implications of changes in supplies, production capacity and demand. In the second stage, Section 5 mimics the different degrees of the "Malacca Trap" by varying the volumes of crude oil import that are allowed to flow through the Strait of Malacca in 8 sea ports situated to the south of Shanghai port. The resulting flows of oil from the supply cities to the refineries and from the refineries to the end cities are observed and compared against those established earlier. Section 6 summarizes the key findings and concludes the paper.

\section{Literature review}

Rimmer and Lee (2007) recognized that the Straits of Malacca offers the shortest and quickest route between the Middle East Gulf and East Asia. And in particular, to China, the Straits of Malacca is a vital artery not only because it presents the shortest route but it is also the most secure by virtue of its serviceable navigational aids. The authors estimated the distances, time and cost involved for tanker shopping of route diversion from Straits of Malacca. Zhang (2011) foresees that China will continue to rely on their main suppliers in Middle East, Venezuela and other oil rich countries in Africa given the limits to further diversify its oil imports. In the events of territorial disputes, pirate attacks and geopolitics, China's seaborne foreign oil supply through the Strait of Malacca can potentially threatened the nation's energy supply-chain security.

In connection, Shaikh et al. (2016) suggested that route diversification to one of increased reliance on pipelines is a potential strategy for addressing this challenge. From the perspective of supply time frames, costs, energy consumed and GHG emissions, Shaikh et al. examined 5 possible routes, of which 2 are pure marine routes and 3 are marine-cum-pipeline routes. They noted that the existing direct marine routes West Africa-China and Middle East-China are presently carrying significant amounts of imported oil, and have to travel long distance and passage through the Strait of Malacca. Therefore, these routes would face all three challenges arising territorial disputes, pirate attacks and geopolitics. In comparison, the oil supplies from the marine-cumpipeline routes like West Africa-Myanmar-China and Middle East-Myanmar-China would only experience geopolitical factors and pirate attacks. The proposed Middle East-Pakistan-China route (of the Pakistan-China Energy and Economic Corridor) would take the shortest time among all the routes, and it offered less per barrel transport cost among all marine cum pipeline routes; it would also consume less transport energy and emit less GHG emissions. Lee et al. (2018) highlighted that through the proposed China-Pakistan Economic Corridor and the Bangladesh-China-IndiaMyanmar Economic Corridor, China will be able to transport oil and LNG (Liquefied Natural Gas) from Iran and Iraq directly by train to China, rather than by sea. These plans would have a major impact on container and liquid cargo movements in the 
Middle East and Europe, as well as, on Shanghai's trans-shipment trade through the Malacca Strait.

Sheu and Kundu (2017) conducted a simulation using the proposed spatial-temporal logistics interaction model to forecast time-varying logistics distribution flows along the various oil supply routes to China. The authors develop an initial transition matrix and estimate the stochastic row vector in the Markov model to predict the flow pattern along all of the transit routes under study. The time-varying logistics distribution flow pattern that was predicted by the Markov model justifies the basic logic of the flow distribution; and results from the study suggest that both transit routes via Gwadar (in the China-Pakistan economic corridor) and Myanmar-China oil pipeline complement each other in handling uncertainty in response to any blockade in the Strait of Malacca. Additionally, for transporting oil from the Middle East to China via Gwadar rather than Myanmar is identified as the more cost-effective route if the pipeline is used as the means of transportation from Gwadar to Kashgar, China. Similarly, in transporting oil from West Africa, the Myanmar-China oil pipeline route may be more cost-effective than the Gwadar route. However, both routes must be used in order to meet the oil requirement of China.

\section{Intermodal network optimization model}

The intermodal network optimisation model consists of three distinct groups of nodes namely supply, intermediate and demand. Import cities for crude oil supply include inland cities which are at the end points of the oil pipelines, as well as, the coastal cities where crude oil are delivered by tankers to the ports. Refinery plants are the intermediate nodes where crude oil is being processed. Demand cities and hinterlands are areas where demand for refined oil is identified. Crude oil pipelines are planned from supply cities to refineries for transportation and refined oil pipelines are planned for the transportation of oil from refineries to the demand cities (Liang, 2017).

\section{Model formulation}

Two components are involved in the construction of the intermodal network optimisation model: a cost model and a goal programming model. The intermodal transportation cost model is developed to represent the cost of transportation between any of the supply-intermediate and intermediate-demand combinations while the goal programming model is used to generate the optimized solution by varying the volume of shipment along any of the supply-intermediate and intermediate-demand node combinations as input variables, to achieve minimum overall cost of the network. The objective of this model is to fulfil the oil demand at the demand cities with the lowest possible aggregate cost, by varying supply quantities and transportation quantities between the supply, intermediate and demand nodes (Liang, 2017). Notations used in this paper are summarized and explained in Table 5 , followed by equations used.

Notations and definitions.

$l=$ number of supply cities for crude oil imports.

$m=$ number of refinery plants where crude oil is being processed into oil products.

$n=$ number of demand cities and hinterlands for oil products.

$S_{i}=$ annual import capacity at supply city $i$. 
$K_{j}=$ annual potential capacity an oil refinery plant $j$

$D_{k}=$ annual demand for oil products at demand city $k$

$c_{i j}=$ cost of shipping one unit volume of crude oil through one unit distance crude oil pipeline from supply city $i$ to refinery $j$

$c_{j k}=$ cost of shipping one unit volume of oil products through one unit distance oil product pipeline from refinery $j$ to demand city $k$

$d_{i j}=$ total distance for shipping crude oil from supply city $i$ to refinery plant $j$

$d_{j k}=$ total distance for shipping oil products from refinery $j$ to demand city $k$

$Q_{i j}=$ volume of crude oil transported from supply city $i$ to refinery plant $j$ via crude oil pipeline

$Q_{j k}=$ volume of oil product transported from refinery plant $j$ to demand city $k$ via oil product pipeline

$\left(x_{i}, y_{i}\right)=$ coordinate location of supply city $i$

$\left(x_{j}, y_{j}\right)=$ coordinate location of intermediate refinery $j$

$\left(x_{k}, y_{k}\right)=$ coordinate location of demand city and hinterland $k$

$$
\begin{aligned}
& d_{i j}=\sqrt{\left(x_{i}-x_{j}\right)^{2}+\left(y_{i}-y_{j}\right)^{2}} \\
& d_{j k}=\sqrt{\left(x_{j}-x_{k}\right)^{2}+\left(y_{j}-y_{k}\right)^{2}}
\end{aligned}
$$

The distance $d_{i j}(1)$ between any of the supply city $i$ and oil refinery $j$, distance $d_{j k}$ (2) between any of the oil refinery $j$ and demand city $k$, can be calculated using the coordinates of the nodes. It is assumed that all supply, intermediate and demand nodes can be located as grid points in a plane. All distances can be calculated as the geometric distance between any of the two points on the planes. Assuming that the transportation cost along the crude oil pipeline and oil product pipelines grow linearly with the volume of oil transported along, cost of transporting oil between any two nodes can thus be estimated.

Objective function

$$
\operatorname{Min} Z=\sum_{j=1}^{m} \sum_{i=1}^{l} Q_{i j} d_{i j} c_{i j}+\sum_{k=1}^{n} \sum_{j=1}^{m} Q_{j k} d_{j k} c_{j k}
$$

Subject to

$$
\begin{aligned}
& \sum_{j=1}^{m} Q_{j k}=D_{k} \text { for } k=1, \ldots, n \\
& \sum_{i=1}^{l} Q_{i j} \leq K_{j} \text { for } j=1, \ldots, m \\
& \sum_{j=1}^{n} Q_{i j} \leq S_{i} \text { for } i=1, \ldots, l \\
& \sum_{i=1}^{l} Q_{i j}=\sum_{k=1}^{n} Q_{j k} \text { for } j=1, \ldots, m
\end{aligned}
$$

The objective function (3) minimizes the total cost of transportation in the transportation network, which comprises the crude oil pipeline and the oil product pipeline 
section. The constraint in eq. (4) required that the demand for oil products at all demand cities are fulfilled. Constraint (5) states that all oil refineries are operating within their maximum designed capacity. Constraint (6) makes sure that all supply cities are supplying within their maximum designed oil import volume. Constraint (7) is based on the assumption that the ratio for crude oil input: oil product output at any of the oil refineries is $1: 1$.

\section{Intermodal transportation cost modelling}

The cost model starts with the identification of supply, intermediate and demand nodes. For each node, the $(x, y)$ location coordinates are recorded down and the distance between any of the two nodes are thus calculated using formulas (1) and (2).

\section{Unit cost for crude oil transportation via pipeline}

To estimate the crude oil transportation cost, the average of two existing crude oil pipeline projects under the "One Belt, One Road" initiative is used and the unit variable crude oil transportation cost per ton per km is around USD 30 (Chen, 2015).

\section{Unit cost for oil product transportation via pipeline}

Similarly, the average transportation cost of two existing oil product pipelines in China, Lan-Cheng-Yu oil product pipeline and Jiangsu North oil product pipeline is used in the model. Based on the information, the unit variable oil product transportation cost per ton per kilometre is around USD 0.017 (Zhao, 2014).

\section{Goal programming model}

The goal programming model is formulated, and typical sensitivity analysis of Linear Programming is carried out to analyse various scenarios of interest. The objective of this model is to fulfill the oil demand at the demand cities with the lowest possible aggregate cost, by varying supply quantities and transportation quantities between the supply, intermediate and demand nodes. The volume of shipment along any of the supply-intermediate and intermediate-demand node combinations are formulated as input variables and the solution of this model provides an optimized oil supply chain design fulfilling the chosen objective.

\section{Base model solution, sensitivity analysis and discussion}

To gain insights on the strategic intents for a large-scale initiative like OBOR, the network model is applied to study China energy resilience along the supply route. A base model solution is first generated using the constructed intermodal network optimization model to understand the utilization rates at the supply, intermediate and demand nodes. Then, sensitivity analysis is performed for different scenarios regarding future events including during relocation of traditional refinery plants, transportation through the Strait of Malacca and when there is an increase in future crude oil demand. In this paper, the base model solution, effects of transportation through the Strait of Malacca and increase in crude oil demand solutions are analyzed and discussed.

$$
\operatorname{Min} d_{1}^{-}, d_{2}^{+}
$$




$$
\begin{aligned}
& \sum_{j=1}^{m} Q_{j k}+d_{1}^{-}=D_{k} \text { for } k=1, \ldots, n \\
& \sum_{j=1}^{m} \sum_{i=1}^{l} Q_{i j} d_{i j} c_{i j}+\sum_{k=1}^{n} \sum_{j=1}^{m} Q_{j k} d_{j k} c_{j k}-d_{2}^{+}=0 \\
& \sum_{i=1}^{l} Q_{i j} \leq \alpha_{j} K_{j} \text { for } j=1, \ldots, m \\
& \sum_{j=1}^{n} Q_{i j} \leq \beta_{i} S_{i} \text { for } i=1, \ldots, l \\
& \sum_{i=1}^{l} Q_{i j}=\sum_{k=1}^{n} Q_{j k} \text { for } j=1, \ldots, m \\
& \alpha_{j} \in\{0,1\} \text { for } j=1, \ldots, m \\
& \beta_{i} \in[0,1] \text { for } i=1, \ldots, l \\
& d_{1}^{-}, d_{2}^{+} \geq 0
\end{aligned}
$$

The objective function (8) has its first priority set to meet the oil demands at the demand cities in constraint (9) as far as possible; and then seek to minimize the associated total cost of transportation in constraint (10). In the transportation network, which comprises the crude oil pipeline and the oil product pipeline section, constraint (11) states oil refinery $j$ are operating within its maximum designed capacity when $\alpha_{j}=1$ and terminated due to relocation if $\alpha_{j}=0$. The volume of oil reaching the city supply $i$ is given by $\beta_{\mathrm{i}} \mathrm{S}_{\mathrm{i}}$ in Constraint (12) where $\beta_{\mathrm{i}}$ varies between 0 and 1 reflecting the degree of supply disruptions. As before, Constraint (13) is based on the assumption that the ratio for crude oil input: oil product output at any of the oil refineries is 1:1.

\section{Experimental study}

The base model is built using forecasted demand and capacity data in 2023, when all of the planned pipeline projects and refinery projects are completed. The analysis is limited to a total of 19 supply nodes (cities comprising 15 major coastal ports and 4 inland crude oil pipelines along OBOR route), 35 intermediate nodes (refineries including large and medium-scale oil refineries) and 9 demand nodes (national central cities of strategic importance) and a schematic with capacity and fulfillment requirements is shown in Fig. 3.

Information on the capacity and fulfilment requirements are obtained and estimated from multiple sources such as websites of China National Petroleum Corporation (CNPC, 2016), Xinhua news publication (Su, 2013), Bloomberg business news (Guo, 2016), Pakistan national newspaper (Yousafzai, 2016), China Statistical Yearbook (National Bureau of Statistics of China, 2016), China Petroleum and Chemical Corporation (Sinopec, 2015), Shenghong Petrochemical (Shenghong Petrochemical, 2016), China News (China News, 2014), Xinhua news (Xinhua Net, 2013), National Development and Reform Commission, 2016), Xinhua news (Xinhua Net, 2016), Sichuan Government (Bureau of Statistics of Sichuan Province, 2016), Guangdong Government 


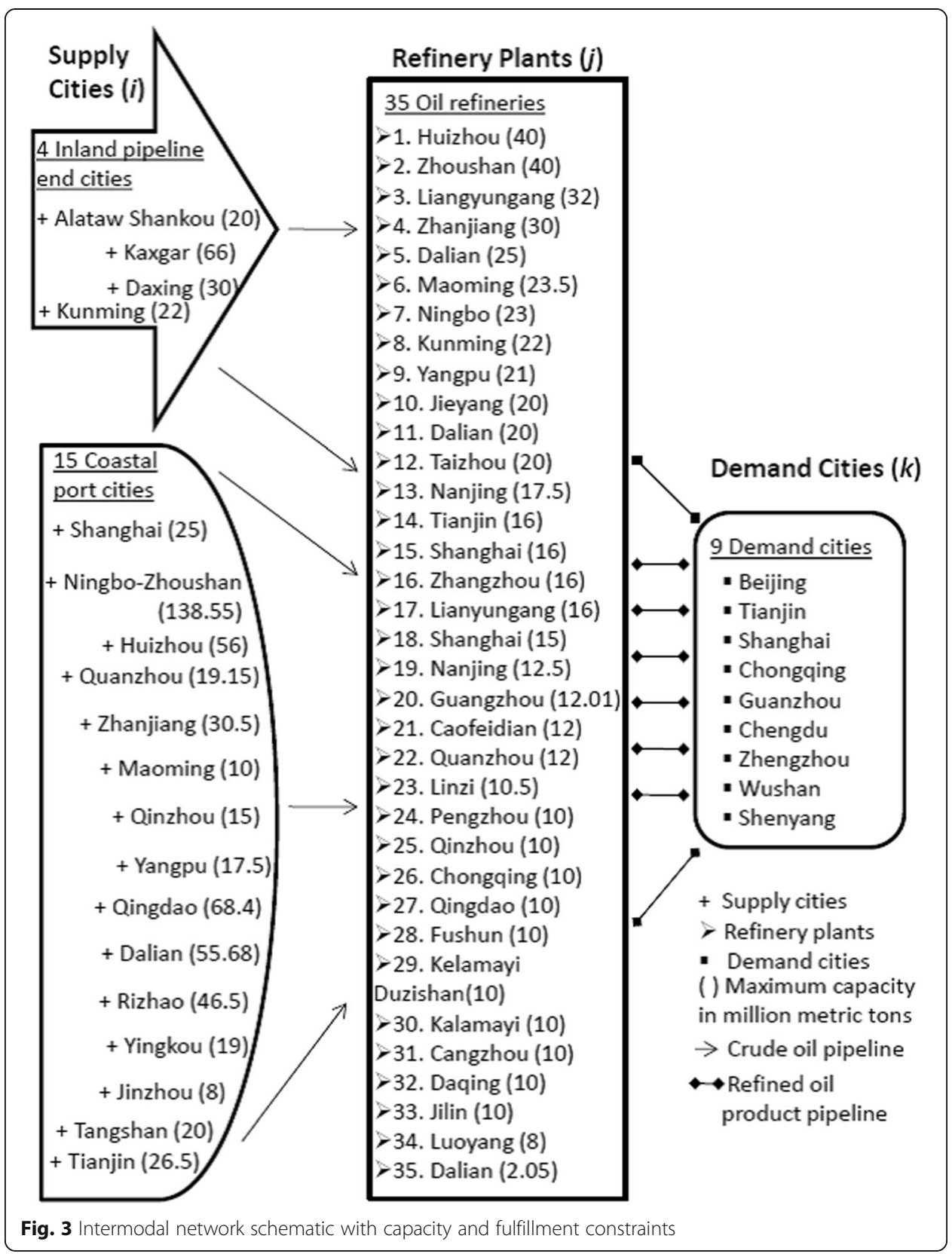

(Bureau of Statistics of Guangdong Province, 2016) and Chengdu Municipal People's Government (Chengdu Municipal People’s Government, 2016).

\section{Analysis for supply nodes}

A summary of the supply node solution is shown in Table 3. It reveals a relatively low percentage utilization rate of the inland pipelines. Although the inland oil pipelines can deliver a total of 138 million tons of crude oil per year, the base solution only assigns a total of 32 million tons of crude oil import to the pipelines, which is equivalent to only 23.18\% utilization to achieve minimal cost objective (Liang, 2017). 
Table 3 Percentage utilizations of inland crude oil pipeline

\begin{tabular}{llll}
\hline Crude oil pipeline project & Supply city & $\begin{array}{l}\text { Maximum planned capacity } \\
\text { (million metric tons per year) }\end{array}$ & $\begin{array}{l}\text { Base solution \% } \\
\text { utilization }\end{array}$ \\
\hline Kazakhstan - China oil pipeline & Alataw Shankou & 20 & $0.00 \%$ \\
Russia-China Ocean oil pipeline & Daqing & 30 & $33.33 \%$ \\
China Trans-Myanmar oil pipeline & Kunming & 22 & $100.00 \%$ \\
China-Pakistan Economic Corridor & Kashgar & 66 & $0.00 \%$ \\
Total & & 138 & $23.18 \%$ \\
\hline
\end{tabular}

(Source: authors' results)

The under-utilization of the inland oil pipelines may be due to the locations of the refinery plants and the demand cities that are mainly in regions with high population density, especially along the coastal line and specifically at the south-east regions (Ge and Feng, 2010). Alataw Shanko and Kashgar, the two inland oil pipelines which are assigned with $0 \%$ utilization, are located along the border of the west and north region. Being extremely far away from the refinery facilities and demand cities, to transport crude oil from Alataw Shankou and Kashgar to intermediate and demand nodes will be economically inefficient, explaining the low planned percentage utilization. Thus, the government has planned for the energy needs in the provinces in northwest regions such as Shaanxi, Gansu, Qinghai, Ningxia and Xinjiang to be better met by wind generated power. Yang et al. (2017) indicated that in China, Inner Mongolia, Xinjiang and Gansu will be the primary provinces for wind power development to support the northwest economic development in the future.

33.33\% utilization is assigned to Daqing, where the Russia-China Eastern SiberiaPacific Ocean oil pipeline ends. This is a result of the well-planned sea ports around the north-eastern coastal line, which started to feed crude oil to refineries since the last century. It can be seen that the crude oil import sea ports along the north-eastern coastal line are assigned high percentage utilization, for example Tianjin port (98.11\%), Dalian port (84.50\%).

In comparison, Kunming crude oil pipeline is assigned $100 \%$ utilization, and all of the supplied crude oil goes to the oil refinery in Kunming, filling the entire capacity of the Kunming refinery plant. This provides support for energy resilience that the China Trans-Myanmar oil pipeline is very much needed to supply crude oil economically to the refinery and the demand in Yunnan province. Table 4 gives the base case solution of crude oil transportation from supply cities to oil refineries.

\section{Analysis for intermediate nodes}

For analysis purposes, refinery projects are categorized into 3 types namely traditional, new and upgrade (Liang, 2017). In this study, a total of 10 traditional,18 new and 7 upgraded refineries are considered.

Traditional projects refer to refinery plants that were built and completed between 1954 and 1993, with majority of them starting operations in the 1970s and 1980s. Among the 10 traditional refinery plants, 5 of them are assigned 100\% utilization (Table 6). The traditional refineries generally have lower capacity and use older generation technology, resulting in higher safety risks and lower standards of pollution control. During 1970s or earlier, the Chinese cities were significantly smaller and many 
Table 4 Base case solutions: From crude oil supply cities to oil refineries
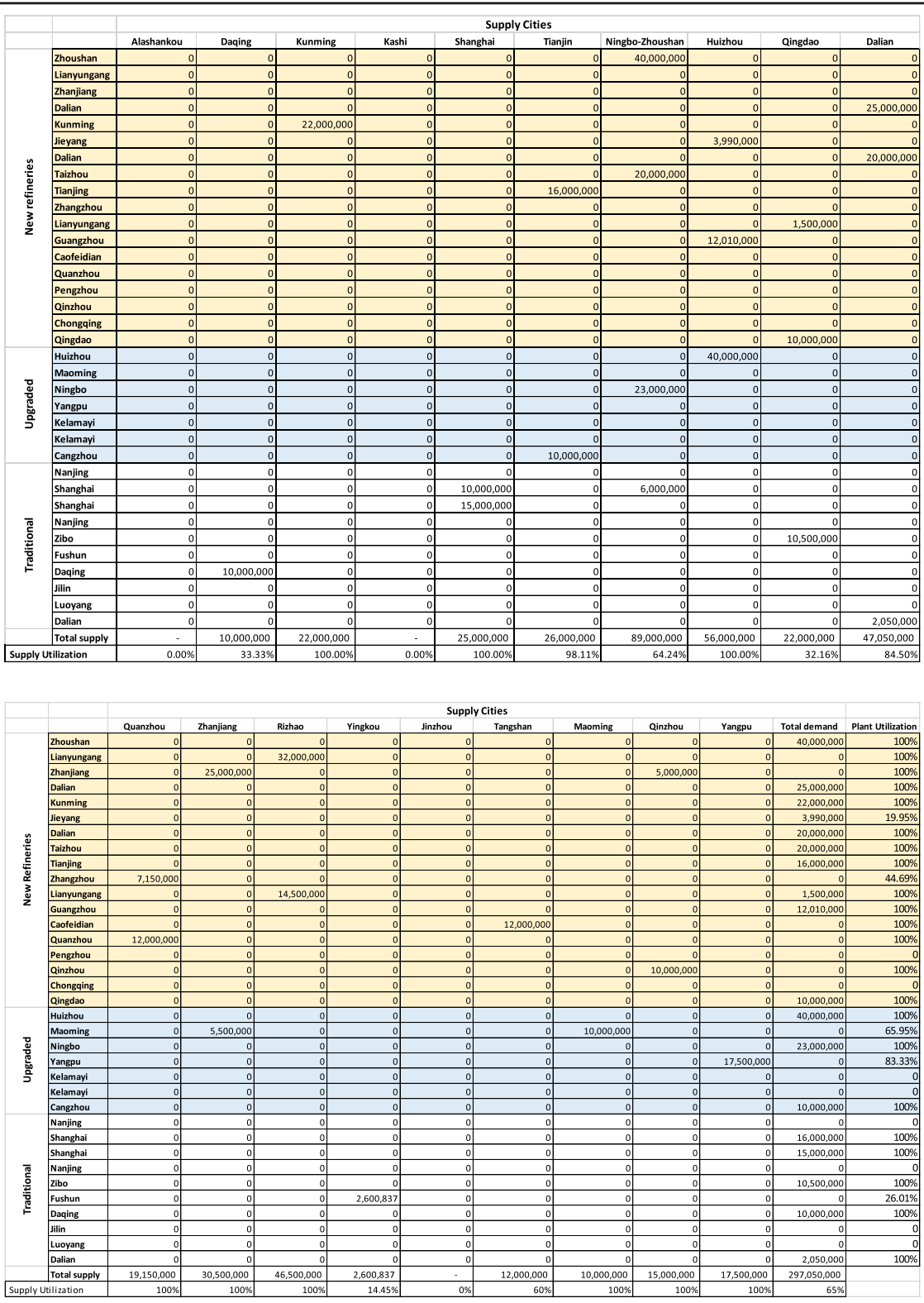

traditional refineries are located in city centres. With the growth in the number of city dwellers, population density and land prices have become are extremely high in recent years. As such, there have been government plans to relocate traditional refineries to designed industrial parks far from city centre. For example, two of the refineries in Nanjing, Jiangsu provinces are planned to relocate to suburb regions (China National Petroleum Corporation, 2014).

New projects refer to plants that were planned and built after 2006. The latest start date among the new refineries is in year 2022. These new refineries are located in industrial parks, far from the residence and economic centres of the city. Fourteen out of 18 new refinery plants are assigned 100\% utilization. Meanwhile, upgrade projects are refineries which had gone through or are currently going through capacity expansion 
construction. The completion of the expansion projects ranges from 2002 to 2020 . Among the 7 upgraded projects, 4 are expected to be fully utilized.

The results of the base model show an alignment with the current refinery planning sitation in China and also serve as a validity check. As shown in Tables $6,77.78 \%$ of the new refinery projects are assigned $100 \%$ utilization, validating that the new plant location choices made by the government and government owned corporations China National Petroleum Corporation (CNPC), China Petroleum and Chemical Corporation (Sinopec) and China National Offshore Oil Corporation (CNOOC) are efficient and appropriate. $57.14 \%$ percent of the upgraded refineries are $100 \%$ utilized in the base model, showing a strong need for the implemented upgraded projects. Lastly, only $50 \%$ of the traditional projects are assigned full utilization in the solution, including four refineries with zero utilization. Two of the Nanjing refineries in Jiangsu province that were planned for relocation are assigned zero utilization, thus concurring with the industrial plans made by the city government. The other 6 refinery plants that are totally unutilized are Jilin, Luoyang, Pengzhou, Chongqing, Kelamayi-Duishan and Kelamayi.

\section{Analysis for demand nodes}

Based on the solutions in Table 5, in order to have their demand fully fulfilled, all cities are supplied by a combination of the nearest oil refineries. For examples, Chongqing obtains its supply from Zhanjiang, Guangzhou, Huizhou, Maoming and Yangpu; Shanghai's demand for oil product is fulfilled by oil products shipped from refineries at Zhousan, Ningbo and both refineries in Shanghai. Even for Shenyang with the lowest demand volume, the city's demand is met by three refineries at Dalian, Fushun and Daqing.

\section{Sensitivity analysis}

In general, it is always more cost economizing to service a refinery plant using the supply closest to it. Shanghai is found to be the most popular supply cities, being the best supply option to 4 refineries in Shanghai, Nanjing and Ningbo. Ningbo-Zhoushan, Qingdao, Dalian, Tianjin, Huizhou and Kunming supply oil to 3 refineries. However, Jinzhou, Maoming and Kashi will not be supplying to any of the refineries.

The allowable decrease is equivalent to the reduced cost when the second-best option is utilized to supply the refinery plants. It represents the incremental cost, should supply in the best option be exhausted or unavailable, and this increment is very significant in most cases. Particularly, the new refinery plants in Pengzhou and Kunming will incur an incremental cost of $\$ 3234$ and $\$ 1345$ per ton of oil, respectively, if the supply from Qinzhou has to be used instead of Kunming (Additional file 1: Table A-1a). The upgraded refinery plant in Kelamayi is expected to experience a jump of \$3029 per ton if Kashi would service the plant rather than Alasankou (Additional file 1: Table A-1b). Similarly, the traditional refinery plant in Daqing is expected to experience a jump of \$1473 per ton if Yingkou would service the plant rather than Daqing (Additional file 1: Table A-1c). The increase in cost of supplying across all refineries is found to be more drastic as it moves down to the less favorable options. Despite these significant cost increase, Rizhao, Yingkou and Qinzhou are still the most preferred backup sources for 5 of the refinery plants followed by Shanghai and Maoming as the next best alternative for another 3 refinery plants. Overall, each of these plants hardly serve more than one city while most cities are 
Table 5 Base case solution: From oil refineries to demand cities

\begin{tabular}{|c|c|c|c|c|c|c|c|c|c|c|}
\hline \multirow{20}{*}{ 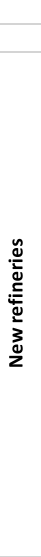 } & & \multicolumn{9}{|c|}{ Demand Cities } \\
\hline & & Beijing & Tianjin & Shanghai & Chongqing & Guangzhou & Chengdu & Zhengzhou & Wuhan & Shenyang \\
\hline & Zhoushan & - & - & $40,000,000$ & - & - & - & \begin{tabular}{|l|}
- \\
\end{tabular} & - & - \\
\hline & Lianyungan & - & $4,101,553$ & - & - & - & - & $27,898,447$ & - & - \\
\hline & Zhanjiang & - & - & - & $30,000,000$ & - & - & - & - & - \\
\hline & Dalian & - & $12,394,936$ & - & - & - & - & - & - & $12,605,064$ \\
\hline & Kunming & - & - & - & - & - & $22,000,000$ & - & - & - \\
\hline & Jieyang & - & - & - & - & $3,990,000$ & - & - & - & - \\
\hline & Dalian & $17,509,663$ & $2,490,337$ & - & - & - & - & - & - & - \\
\hline & Taizhou & - & - & - & - & $7,173,057$ & - & - & $12,826,943$ & - \\
\hline & Tianjing & $16,000,000$ & - & - & - & - & - & - & - & - \\
\hline & Zhangzhou & - & - & - & - & $7,150,000$ & - & - & - & - \\
\hline & Lianyungan: & - & $16,000,000$ & - & - & - & - & - & - & - \\
\hline & Guangzhou & - & - & - & $12,010,000$ & - & - & - & - & - \\
\hline & Caofeidian & $12,000,000$ & - & - & - & - & - & - & - & - \\
\hline & Quanzhou & - & - & - & - & $12,000,000$ & - & - & - & - \\
\hline & Pengzhou & - & - & - & - & - & - & - & - & - \\
\hline & Qinzhou & - & - & - & - & - & $10,000,000$ & - & - & - \\
\hline & Chongqing & - & - & - & - & - & \begin{tabular}{l|l}
- & \\
\end{tabular} & - & - & - \\
\hline & Qingdao & - & $10,000,000$ & - & - & - & - & - & - & - \\
\hline \multirow{7}{*}{ 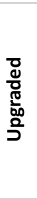 } & Huizhou & - & - & - & $29,266,053$ & $10,733,947$ & - & - & - & - \\
\hline & Maoming & - & - & - & $15,500,000$ & - & - & - & - & - \\
\hline & \begin{tabular}{|l|} 
Ningbo \\
\end{tabular} & - & - & $19,597,443$ & - & - & - & - & $3,402,557$ & - \\
\hline & Yangpu & - & - & - & $4,956,399$ & - & $12,543,601$ & - & - & - \\
\hline & Kelamayi & - & - & - & - & - & - & - & - & - \\
\hline & Kelamayi & - & - & - & - & - & - & - & - & - \\
\hline & Cangzhou & $10,000,000$ & - & - & - & - & - & - & - & - \\
\hline \multirow{10}{*}{ 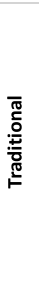 } & Shanghai & - & - & - & - & - & - & - & $16,000,000$ & - \\
\hline & Nanjing & - & - & - & - & - & - & - & - & - \\
\hline & Shanghai & - & - & $13,831,087$ & - & - & - & $1,168,913$ & - & - \\
\hline & \begin{tabular}{|l|} 
Nanjing \\
\end{tabular} & - & - & - & - & - & - & - & - & - \\
\hline & \begin{tabular}{|l|} 
Zibo \\
\end{tabular} & $10,500,000$ & - & - & - & - & - & - & - & - \\
\hline & Fushun & - & - & - & - & - & - & - & - & $2,600,837$ \\
\hline & Daqing & - & - & - & - & - & - & - & - & $10,000,000$ \\
\hline & \begin{tabular}{|l|} 
Jilin \\
\end{tabular} & - & - & - & - & - & - & - & - & - \\
\hline & Luoyang & - & - & - & - & - & - & - & - & - \\
\hline & Dalian & - & $2,050,000$ & - & - & - & - & - & - & - \\
\hline To & Demand & $66,009,663$ & \begin{tabular}{|l}
$4,036,826$ \\
\end{tabular} & $73,428,530$ & $91,732,452$ & $41,047,004$ & $44,543,601$ & $29,067,360$ & \begin{tabular}{|r|}
$32,229,500$ \\
\end{tabular} & $25,205,901$ \\
\hline
\end{tabular}

serviced by a combination of plants (Additional file 1: Table A-2). An exceptional example is Huizhou which represents the second best option to Chongqing and Guangzhou.

Among all those supply cities which are fully exhausting their supplies, if circumstances permit, the China government should consider increase the supplies in Zhoushan, Ningbo, Tianjin, Qingdao, Daqing and Dalian etc. (Table 6). The negative shadow price indicates that as supply increases, the cost of energy supply can be reduced without the refinery plants having to seek their supplies from a more distant source and incurring higher transportation cost. Among the 35 cities, an increase in supply in Tianjin, Qingdao, Daqing and Dalian most significantly reduced cost by $\$ 177$ per ton of crude oil transported.

Similarly, it will be most cost beneficial if the plant capacities in Yangpu, Maoming, Kunming and Zhanjiang can be increased. The figures stand at $\$ 178.35$, $\$ 177.44, \$ 176.58$ and $\$ 163.75$ for the respective plants. In contrast, the cost reduction from plant capacity expansion is only $\$ 42.13$ in Shanghai and $\$ 50.98$ in Huizhou (Table 7).

The energy shipment cost is expected to increase the most drastically should demand increases occurs in Chongqing and Chengdu. The incremental cost, as reflected by the shadow price, stands at $\$ 180$ for both the cities. Based on the forecast, Chongqing presents the highest energy consumption in 2023. While Shanghai has the second highest demand, additional demand do not exert as high a cost pressure compared to other cities (Table 8). 
Table 6 Effect of supply changes at supply cities

\begin{tabular}{|c|c|c|c|c|c|}
\hline Supply Cities & $\begin{array}{l}\text { Supply } \\
\text { Shipped }\end{array}$ & $\begin{array}{l}\text { Shadow } \\
\text { Price }\end{array}$ & $\begin{array}{l}\text { Supply } \\
\text { Capacity }\end{array}$ & $\begin{array}{l}\text { Allowable } \\
\text { Increase }\end{array}$ & $\begin{array}{l}\text { Allowable } \\
\text { Decrease }\end{array}$ \\
\hline Huizhou & $40,000,000$ & -126.89 & $40,000,000$ & $3,990,000$ & $10,733,947$ \\
\hline Zhoushan & $40,000,000$ & -171.77 & $40,000,000$ & $2,600,837$ & $1,168,913$ \\
\hline Lianyungang & $32,000,000$ & -100.15 & $32,000,000$ & $2,600,837$ & $1,500,000$ \\
\hline Zhanjiang & $30,000,000$ & -14.84 & $30,000,000$ & $5,500,000$ & $8,000,000$ \\
\hline Dalian & $25,000,000$ & -161.93 & $25,000,000$ & $2,600,837$ & $7,399,163$ \\
\hline Maoming & $15,500,000$ & 0.00 & $23,500,000$ & $1 E+100$ & $8,000,000$ \\
\hline Ningbo & $23,000,000$ & -170.78 & $23,000,000$ & $2,600,837$ & $1,168,913$ \\
\hline Kunming & $22,000,000$ & 0.00 & $22,000,000$ & $1 E+100$ & 0 \\
\hline Jieyang & $3,990,000$ & 0.00 & $20,000,000$ & $1 E+100$ & $16,010,000$ \\
\hline Dalian & $20,000,000$ & -160.41 & $20,000,000$ & $2,600,837$ & $2,490,337$ \\
\hline Taizhou & $20,000,000$ & -117.09 & $20,000,000$ & $2,600,837$ & $1,168,913$ \\
\hline Nanjing & 0 & 0.00 & $17,500,000$ & $1 \mathrm{E}+100$ & $17,500,000$ \\
\hline Tianjing & $16,000,000$ & -177.80 & $16,000,000$ & 500,000 & $2,490,337$ \\
\hline Shanghai & $16,000,000$ & -129.27 & $16,000,000$ & $2,600,837$ & $1,168,913$ \\
\hline Zhangzhou & $7,150,000$ & 0.00 & $16,000,000$ & $1 E+100$ & $8,850,000$ \\
\hline Lianyungang & $16,000,000$ & -101.18 & $16,000,000$ & $2,600,837$ & $1,500,000$ \\
\hline Shanghai & $15,000,000$ & -134.35 & $15,000,000$ & $2,600,837$ & $1,168,913$ \\
\hline Yangpu & $17,500,000$ & 0.00 & $21,000,000$ & $1 E+100$ & $3,500,000$ \\
\hline Nanjing & 0 & 0.00 & $12,500,000$ & $1 E+100$ & $12,500,000$ \\
\hline Guangzhou & $12,010,000$ & -75.12 & $12,010,000$ & $3,990,000$ & $10,733,947$ \\
\hline Caofeidian & $12,000,000$ & -168.12 & $12,000,000$ & $2,600,837$ & $2,490,337$ \\
\hline Quanzhou & $12,000,000$ & -66.94 & $12,000,000$ & $7,150,000$ & $8,850,000$ \\
\hline Zibo & $10,500,000$ & -44.72 & $10,500,000$ & $2,600,837$ & $2,490,337$ \\
\hline Pengzhou & 0 & 0.00 & $10,000,000$ & $1 E+100$ & $10,000,000$ \\
\hline Qinzhou & $10,000,000$ & -121.60 & $10,000,000$ & $5,000,000$ & 4,956,399 \\
\hline Chongqing & 0 & 0.00 & $10,000,000$ & $1 E+100$ & $10,000,000$ \\
\hline Qingdao & $10,000,000$ & -177.46 & $10,000,000$ & $2,600,837$ & $7,399,163$ \\
\hline Fushun & $2,600,837$ & 0.00 & $10,000,000$ & $1 E+100$ & $7,399,163$ \\
\hline Kelamayi & 0 & 0.00 & $10,000,000$ & $1 E+100$ & $10,000,000$ \\
\hline Kelamayi & 0 & 0.00 & $10,000,000$ & $1 E+100$ & $10,000,000$ \\
\hline Cangzhou & $10,000,000$ & -144.71 & $10,000,000$ & 500,000 & $2,490,337$ \\
\hline Daqing & $10,000,000$ & -177.09 & $10,000,000$ & $2,600,837$ & $7,399,163$ \\
\hline Jilin & 0 & 0.00 & $10,000,000$ & $1 E+100$ & $10,000,000$ \\
\hline Luoyang & 0 & 0.00 & $8,000,000$ & $1 E+100$ & $8,000,000$ \\
\hline Dalian & $2,050,000$ & -177.30 & $2,050,000$ & $2,600,837$ & $2,050,000$ \\
\hline
\end{tabular}

Finally, the shadow prices resulting from violation of the flow conservation constraints at the plant is quite similar to those for the increment of end demand at the cities. The sensitivity analysis report table is omitted for brevity

\section{Effects of "Malacca trap" and shift of crude oil by sea route and/or inland oil pipelines}

Since early this century, Middle-East countries are the major crude oil suppliers to China and the shortest and safest way to ship the imported crude oil to China is 
Table 7 Effect of capacity changes at refinery plants

\begin{tabular}{|c|c|c|c|c|c|}
\hline Refinery Plants & $\begin{array}{l}\text { Capacity } \\
\text { Utilized }\end{array}$ & $\begin{array}{l}\text { Shadow } \\
\text { Price }\end{array}$ & $\begin{array}{l}\text { Capacity } \\
\text { Available }\end{array}$ & $\begin{array}{l}\text { Allowable } \\
\text { Increase }\end{array}$ & $\begin{array}{l}\text { Allowable } \\
\text { Decrease }\end{array}$ \\
\hline Alashankou & 0 & 0.00 & $20,000,000$ & $1 E+100$ & $20,000,000$ \\
\hline Daqing & $10,000,000$ & 0.00 & $30,000,000$ & $1 E+100$ & $20,000,000$ \\
\hline Kunming & $22,000,000$ & -176.58 & $22,000,000$ & 0 & $1,168,913$ \\
\hline Kashi & 0 & 0.00 & $66,009,810$ & $1 E+100$ & $66,009,810$ \\
\hline Shanghai & $25,000,000$ & -42.13 & $25,000,000$ & $6,000,000$ & $10,000,000$ \\
\hline Tianjin & $26,000,000$ & 0.00 & $26,500,000$ & $1 E+100$ & 500,000 \\
\hline Ningbo-Zhoushan & $89,000,000$ & 0.00 & $138,550,000$ & $1 E+100$ & $49,550,000$ \\
\hline Huizhou & $56,000,000$ & -50.98 & $56,000,000$ & $2,600,837$ & $1,168,913$ \\
\hline Qingdao & $22,000,000$ & 0.00 & $68,400,000$ & $1 E+100$ & $46,400,000$ \\
\hline Dalian & $47,050,000$ & 0.00 & $55,680,000$ & $1 E+100$ & $8,630,000$ \\
\hline Quanzhou & $19,150,000$ & -108.76 & $19,150,000$ & $2,600,837$ & $1,168,913$ \\
\hline Zhanjiang & $30,500,000$ & -163.75 & $30,500,000$ & $2,600,837$ & $1,168,913$ \\
\hline Rizhao & $46,500,000$ & -55.75 & $46,500,000$ & $1,500,000$ & $14,500,000$ \\
\hline Yingkou & $2,600,837$ & 0.00 & $18,000,000$ & $1 E+100$ & $15,399,163$ \\
\hline Jinzhou & 0 & 0.00 & $8,000,000$ & $1 E+100$ & $8,000,000$ \\
\hline Tangshan & $12,000,000$ & 0.00 & $20,000,000$ & $1 E+100$ & $8,000,000$ \\
\hline Maoming & $10,000,000$ & -177.44 & $10,000,000$ & $2,600,837$ & $1,168,913$ \\
\hline Qinzhou & $15,000,000$ & -55.52 & $15,000,000$ & $2,600,837$ & $1,168,913$ \\
\hline Yangpu & $17,500,000$ & -178.35 & $17,500,000$ & $2,600,837$ & $1,168,913$ \\
\hline
\end{tabular}

through the Strait of Malacca. It is estimated that over $80 \%$ of the Chinese crude oil by sea is imported through this route (Friedman, 2017). However, as the Strait of Malacca is narrow and theoretically it can be completely not accessible once the dominate country decided to stop China's ships from passing through, it gives rise to the term "the Malacca Trap" (Khanna, 2016).

Based on the network model, seaports situated to the south of Shanghai port are affected significantly if the connectivity through the Strait of Malacca is constrained. The eight ports that are directly and significantly affected by the "Malacca Trap" are shown in Table 9. The network model was run repeatedly to observe the associated route shifts as the volume of crude oil allowed to pass through the Strait of Malacca varies, from $100 \%$ to $0 \%$ of the base model (Liang, 2017).

\section{Change of crude oil import source, under "Malacca trap"}

In the case when there exists a limitation on volume of crude oil import through the Strait of Malacca, the oil demand will shift to other routes including the RussianChina oil pipeline, Kazakhstan-China oil pipeline, trans-Myanmar oil pipeline, Pakistan-China oil pipeline and all seaports not affected by the "Malacca Trap". Figures 4 and 5 show the growth of crude oil volume through the inland oil pipelines. Figures 6 and 7 show the growth of crude oil volume through the seaports not affected by the "Malacca Trap".

Based on the solution, it is observed when connectivity through Strait of Malacca drops under 25\%, the crude oil import volume through Alataw Shankou pipeline and 
Table 8 Effect of demand changes at demand cities

\begin{tabular}{llllll}
\hline Demand Cities & Demand Fulfilled & Shadow Price & Potential Demand & Allowable Increase & Allowable Decrease \\
\hline Beijing & $66,009,663$ & 177.96 & $66,009,663.00$ & $2,490,337$ & $2,600,837$ \\
Tianjin & $47,036,826$ & 177.84 & $47,036,826.10$ & $7,399,163$ & $2,600,837$ \\
Shanghai & $73,428,529$ & 176.66 & $73,428,529.40$ & $1,168,913$ & $2,600,837$ \\
Chongqing & $91,732,453$ & 180.20 & $91,732,452.70$ & $1,168,913$ & $2,600,837$ \\
Guangzhou & $41,047,004$ & 178.33 & $41,047,004.00$ & $1,168,913$ & $2,600,837$ \\
Chengdu & $44,543,601$ & 180.90 & $44,543,600.60$ & $1,168,913$ & $2,600,837$ \\
Zhengzhou & $29,067,360$ & 177.97 & $29,067,359.90$ & $4,101,553$ & $2,600,837$ \\
Wuhan & $32,229,500$ & 177.58 & $32,229,500.00$ & $1,168,913$ & $2,600,837$ \\
Shenyang & $25,205,901$ & 177.67 & $25,205,901.40$ & $7,399,163$ & $2,600,837$ \\
\hline
\end{tabular}

Daqing pipeline rise to $100 \%$ as existing crude oil supply nodes could not fulfill the demand fully. On the contrary, oil import through Kashgar (Pakistan pipeline) does not increase until the capacity at other import routes, both seaports and pipelines are fully utilized. This is logical as Kashgar is far away from all oil refineries and demand cities and it is not economical to utilize Kashgar pipeline when there is still unexploited capacity at other supply nodes. The solution showed the oil pipelines along the OBOR route enhances China supply resilience.

Figures 8 and 9 show the percentage volume oil import through three major routes including pipeline and seaport from Russia, sea route through the Malacca Strait and the Pakistan-China oil pipeline connecting China to Gwadar port and then directly to the Persian Gulf. Figure 10 shows when crude oil import from Russia is kept constantly at $36.90 \%$ of total oil imports, import of oil take the alternative route through the Gwadar port and then through Pakistan-China pipeline (Liang, 2017).

Figure 11 shows when crude oil import from other sources could increase to substitute for oil imported through the Strait of Malacca, oil import from Russia grows faster than oil via Pakistan-China pipeline as the location of ports connected to Russia are closer to oil refineries and demand city nodes. Volume through Pakistan-China pipeline only starts to increase when the Strait of Malacca connectivity drops beyond 50\%.

\section{Impact of increase in crude oil demand}

Assuming China's demand for crude oil will increase by $2.5 \%$ annually till year 2030 and if there is no development in crude oil mining within the Chinese territory, the additional requirements need to be fulfilled by oil imports from foreign countries. To understand the impact of future crude oil demand, sensitivity analysis was performed by varying the percentage of crude oil change in annual crude oil demand. The base model was built using forecasted demand and capacity data in 2023, when all planned pipeline projects and refinery projects are completed and the sensitivity analysis in this case covered the projected crude oil demand from year 2021 to 2025.

Figure 10 shows that the largest section of crude oil import will come via seaports (as shaded accordingly), specifically from seaports that could be directly impacted by the Malacca Strait which is consistent with previous cases and coincides with the current import situation. Since around $80 \%$ of China's current crude 
Table 9 Crude oil supply nodes affected by "Malacca Trap"

\begin{tabular}{|c|c|c|}
\hline Type & Supply node & $\begin{array}{l}\text { Maximum planned crude oil } \\
\text { import capacity (million metric tons) }\end{array}$ \\
\hline \multirow[t]{4}{*}{ Four (4) inland pipeline projects } & Alataw Shankou & 20 \\
\hline & Daqing & 30 \\
\hline & Kunming & 22 \\
\hline & Kashgar & 66 \\
\hline \multirow{8}{*}{$\begin{array}{l}\text { Eight (8) seaports directly impacted } \\
\text { by the "Malacca Trap" }\end{array}$} & Shanghai & 25 \\
\hline & Ningbo-Zhousan & 138.55 \\
\hline & Huizhou & 56 \\
\hline & Quanzhou & 19.15 \\
\hline & Zhanjiang & 30.5 \\
\hline & Maoming & 10 \\
\hline & Qinzhou & 15 \\
\hline & Yangpu & 17.5 \\
\hline \multirow{7}{*}{$\begin{array}{l}\text { Seven (7) seaports not impacted by } \\
\text { the "Malacca Trap" }\end{array}$} & Qingdao & 68.4 \\
\hline & Dalian & 55.68 \\
\hline & Rizhao & 46.5 \\
\hline & Yingkou & 18 \\
\hline & Jinzhou & 8 \\
\hline & Tangshan & 20 \\
\hline & Tianjin & 26.5 \\
\hline
\end{tabular}

import has to go through the Malacca Strait and as the annual demand for crude oil increases, the increases in demand have to come mainly from Alataw Shakou, where the Kazakhstan-China oil pipeline ends, along the OBOR route. As Kunming oil pipeline has been consistently utilized with maximum capacity throughout the different cases, the study suggests a possibility for expanding the capacity to further enhance China's energy resilience.

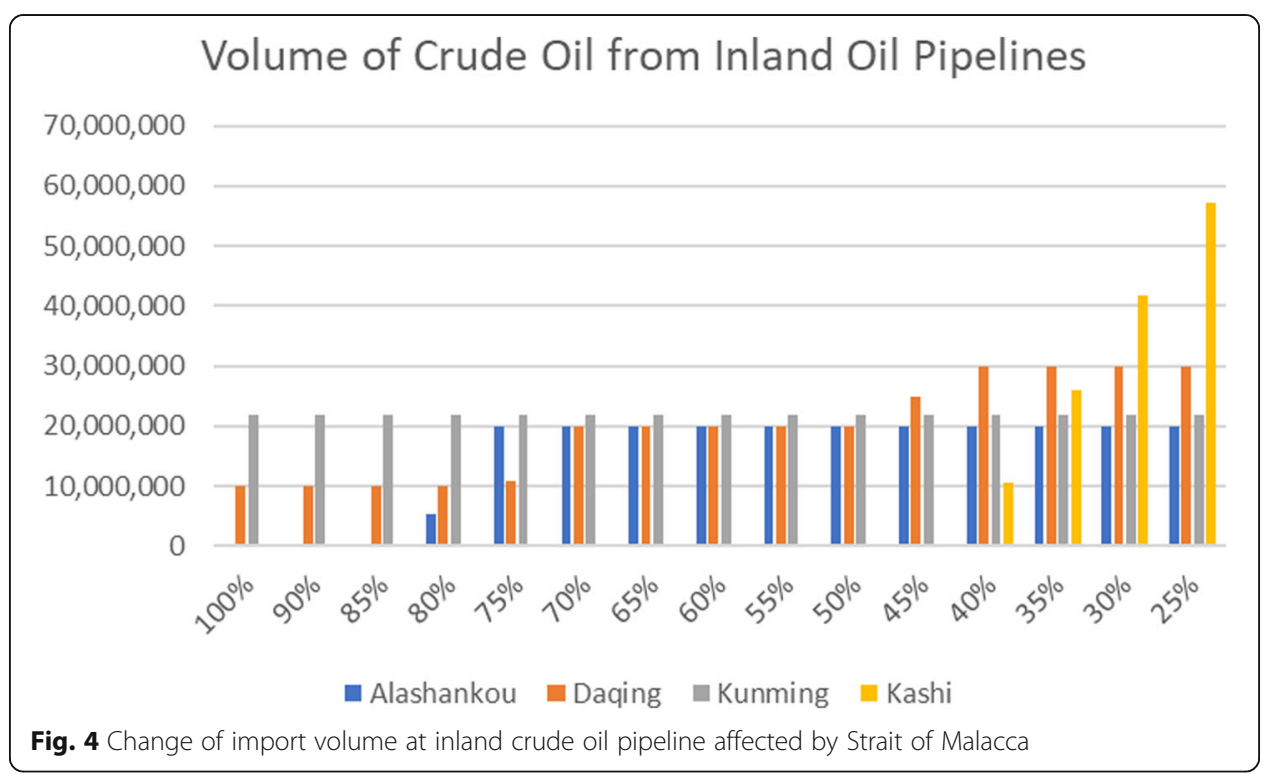




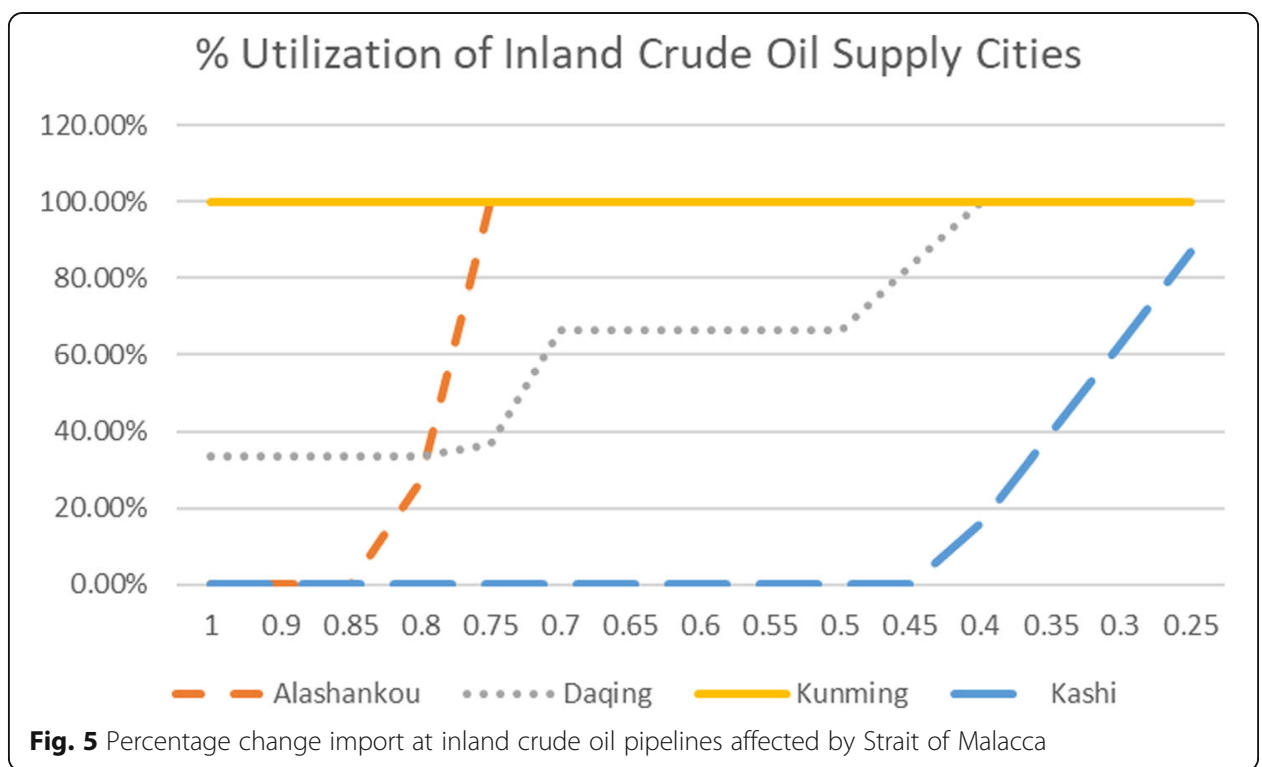

\section{Conclusion and policy implications}

The rapidly growing Chinese economy and its insatiable appetite for oil have made China increasingly dependent on imported oil and as the world proven oil reserves are in the Middle East, Latin America, North America and Africa and West European countries, the imported oil has to go through the Strait of Malacca and South China Sea. This paper examines China's current level of trading and key energy projects along OBOR to provide insights to understand its strategic intent.

Results from this study has shown Shanghai to be the most popular supply cities, followed by Kunming, Alasankou and Daqing, as these cities are able provide the lowest shipping cost of crude oil to major refineries considered in the sample. As multiple refinery plants are used to serve each and every city, the fulfilment of the end demand can be ensured. To further secure China's energy supply, it is observed the energy-

\section{Volume of Crude Oil Imports from Seaport Supply Cities not Directly Affected by "Malacca Trap"}

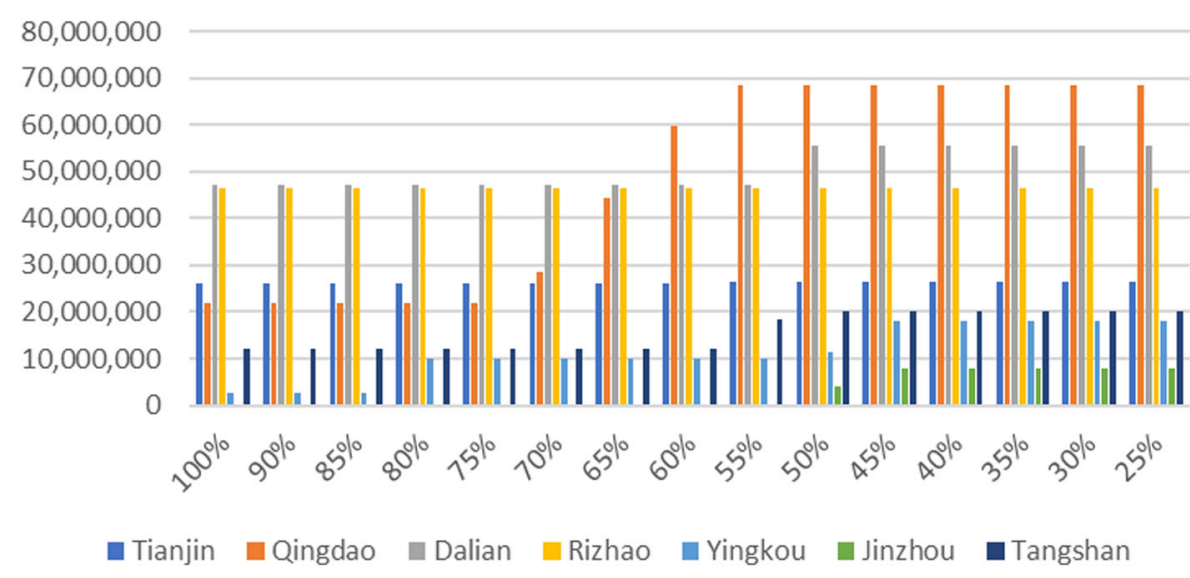

Fig. 6 Import volumes at seaports affected by Strait of Malacca 


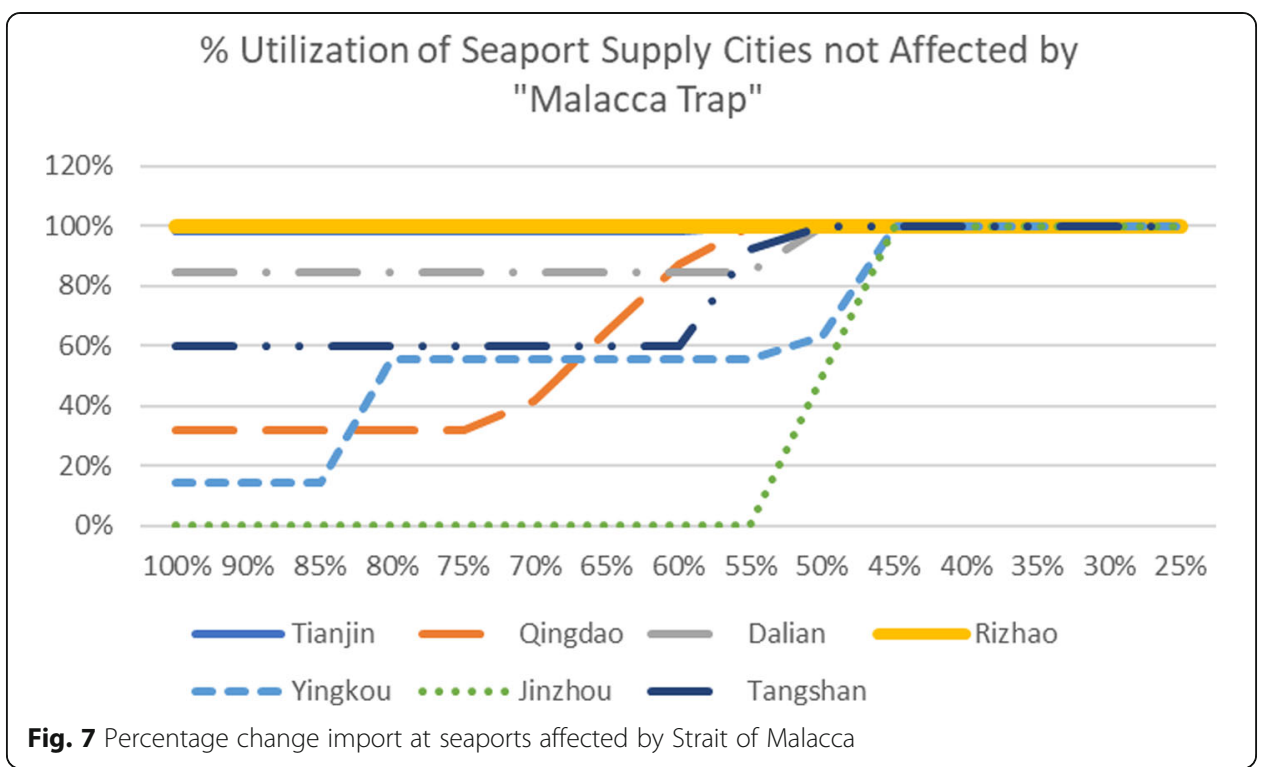

related infrastructure projects undertaken by the Chinse government are closely connected to the current and proven oil and natural gas reserves locations. Of particular interest is the constructions of the pipelines alongside with the relocations and upgrading of existing refineries and establishments of new ones. As new and upgraded refineries process increasing oil volumes and the older plants face a corresponding decline, Kunming crude oil pipeline is expected to enjoy a full utilization rate. Kunming crude oil pipeline provides the necessary support to the China Trans-Myanmar oil pipeline, which is very important for the energy resilience of China. It supplies crude oil economically to the refinery to satisfy the demand in Yunnan province. Meanwhile, Daqing (where the Russia-China Eastern Siberia-Pacific Ocean oil pipeline ends) enjoys a moderately good degree of utilization due to the presence of well-planned seaports including Tianjin and Dalian. In the subsequent analysis of the "Malacca Trap", the

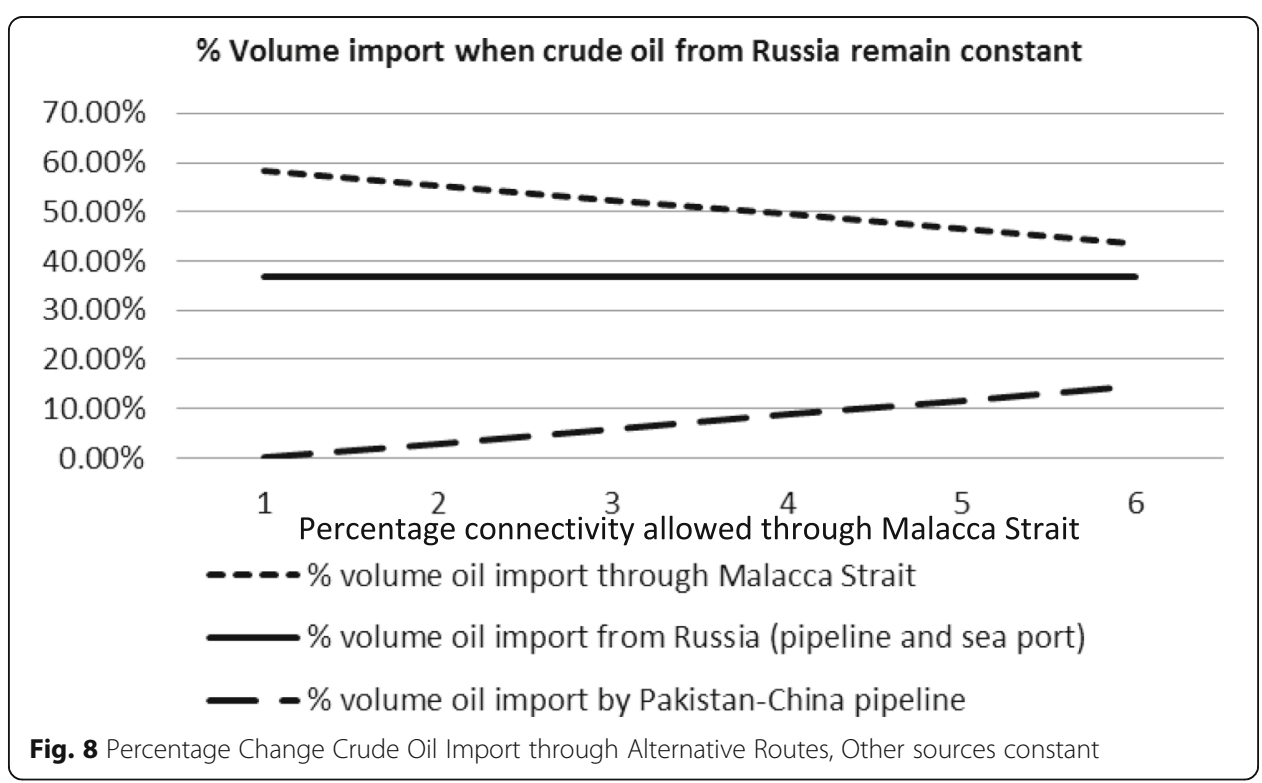



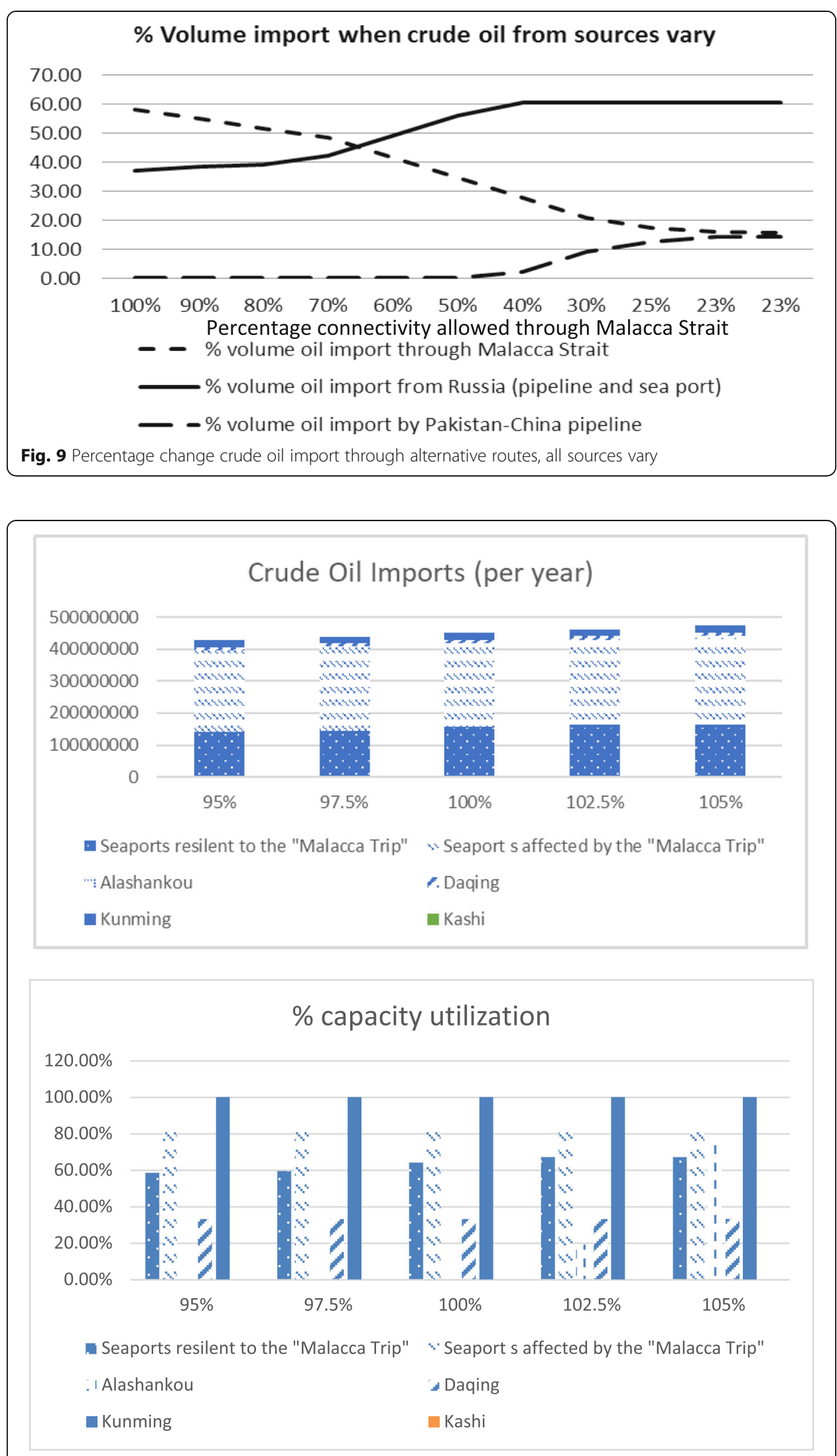

Fig. 10 Result of sensitivity analysis by varying China's annual crude oil demand 
transportation of oil is shown to divert from the ports of Shanghai, Ningbo Zhousan, Huizhou, Quanzhou, Zhanjiang, Maoming, Qinzhou and Yangpu to other routes including the Russian-China oil pipeline, Kazakhstan-China oil pipeline, trans-Myanmar oil pipeline, Pakistan-China oil pipeline and all other seaports if the connectivity through the Strait of Malacca is constrained. Specifically, the Alataw Shankou pipeline and Daqing pipeline, as well as, Yingkou, Qingdao and Tangshan ports, will be the more attractive next best options compared to going through the Gwadar port or the Pakistan-China oil pipeline.

Notwithstanding the limitations that storage and production costs are not considered in the study, the solutions generated by the intermodal network optimization model suggest the OBOR initiative is for more than trade. During prolonged periods of supply uncertainties, the pipelines will provide an alternative channel to import the crude oil required by the country and, hence, enhances China energy resilience.

\section{Supplementary information}

Supplementary information accompanies this paper at https://doi.org/10.1186/s41072-020-0058-1.

Additional file 1.

\section{Abbreviations}

BRI: Belt and Road Initiative; EIA: US Energy Information Administration; IEA: International Energy Agency; OBOR: One Belt, One Road; PPD: US Presidential Policy Directive; RMB: Chinese currency Renminbi

\section{Acknowledgements}

The author would like to thank Ms. Liang Jiangyi for conducting literature search for websites from China; and Mr. Jerry Tan, Adjunct Senior Fellow of TDSI for compilations of earlier versions of this manuscript.

\section{Authors' contributions}

LC identified the energy supply routes in the Intermodal Network Optimization Model, and operationalized the model using real data. JL reviewed the extant literature and conducted the sensitivity analysis to obtain further insights on the empirical findings. Both authors read and approved the final manuscript."

\section{Authors' information}

Joyce is an Assistant Professor of Operations Management (Education) at the Singapore Management University. Her research mainly focuses logistics, transportation and maritime. She has written and published several papers in fieldjournals specific to those aforementioned areas. She is currently chairing the MBOT (Maritime Business \& Operations Track) committee at her university. Loon Ching Tang is professor and head of Department of Industrial Engineering in NUS. He holds a Ph.D. degree from Cornell University in the field of Operations Research. He has been engaged in many industry projects involving innovative applications of optimization techniques, stochastic modeling and statistical analysis.

He has published widely in more than 30 different international peer-reviewed journals of which more than 100 papers are included in SCl. He has been on the editorial review board of the Journal of Quality Technology since 2007 and has been an active reviewer for more than 30 international journals. He is the recipient of the 2012 E.A. Evans/P.K. McElroy Award and the 2004 Stan Ofsthun Award both at the Annual RAMS. He has also received the 2010 Best Application Paper Award from IIE Transactions.

He is the main author of the book, "Six Sigma: Advanced Tools for BB and MBB" (John Wiley), which was presented with the inaugural Masing Book Prize by the International Academy for Quality. He is also the co-author of a book on stochastic processes, Markov-Modulated Processes and Semiregenerative Phenomena; and the co-editor of Advances in Maritime Logistics and Supply Chain Systems.

\section{Funding}

The research was conducted at the Future Resilient Systems at the Singapore-ETH Centre, which was established collaboratively between ETH Zurich and Singapore's National Research Foundation (FI 370074011) under its Campus for Research Excellence and Technological Enterprise program.

Availability of data and materials

All data generated or analyzed during this study are included in this published article. 


\section{Author details}

1Department of Industrial and Systems Engineering, National University of Singapore, Block E1 \#05-05, 1 Engineering Drive 2, Singapore 117576, Singapore. ${ }^{2}$ Singapore Management University, Lee Kong Chian Business School, 50 Stamford Road, \#05-01 Singapore 178899, Singapore.

Received: 18 July 2019 Accepted: 31 January 2020

Published online: 17 February 2020

\section{References}

BP. 2017. Statistical review of world energy. June

Bureau of Statistics of Guangdong Province. 2016. Population Guangzhou. 12 April. http://www.gzstats.gov.cn/tjyw/201604/t2 0160412_39495.htm (last Accessed 21 Mar 2017)

Bureau of Statistics of Sichuan Province. 2016. Chengdu Population. 20 May. http://www.sc.stats.gov.cn/web/a_xjdetails.jsp; jsessionid=1EF3D2C59B7B7ECA9425A7D4897 5BF8E (last Accessed 21 Mar 2017)

Cao W, Bluth C (2013) Challenges and counter measures of China's energy security. Energy Policy 53:381-388

Chan S (2017) The belt and road initiative: China's financing efforts and implications. In: East Asian Institute Background working paper Brief Number 1277: 1. National University of, Singapore, pp 17-18

Chen F. 2015. Oil observation: 2014 Kazakhstan crude oil export status and trend analysis. 02 February. http://oilobserver. com/tendency/article1456 (last Accessed 21 Mar 2017)

Cheng L (2016) Three questions on China's "belt and road initiative". China Econ Rev 40:309-313

Chengdu Municipal People's Government. 2016. Chengdu Population. http://www.chengdu.gov.cn/servicelist/cdgk02/ (last Accessed 21 Mar 2017)

China National Petroleum Corporation. 2014. China wants to relocate its refinery to improve air quality. 03 July. http://center. cnpc.com.cn/sysb/system/2014/07/03/001495338.shtml (last Accessed 09 Dec 2017)

China National Petroleum Corporation (CNPC). 2016. https://www.cnpc.com.cn/en/cnpcataglance/cnpcataglance. shtm|\#cnpcataglance

China News. 2014. China Petrochemical Guangdong Petrochemical refinery project will be officially put into operation in 2018.21 July

Chua AC. 2017. One belt one road and opportunities. 06 July. http://www.centerforfinancialstability.org/research/Chua_ OneBeltOneRoad_7_6_17.pdf (last Accessed 09 Dec 2017)

Downs E (2006) Foreign policy studies energy security series: China. Brookings Institution, Washington DC https://www. brookings.edu/wp-content/uploads/2016/06/12china.pdf

EY. 2015. Navigating the belt and road: financial sector paves the way for infrastructure. August. http://www.ey.com/Publication/ vwLUAssets/EY-navigating-the-belt-and-road-en/\$FILE/EY-navigating-the-belt-and-road-en.pdf (last Accessed 09 Dec 2017)

Ge M, Feng Z (2010) Classification of densities and characteristics of curve of population centers in China by GIS. J Geogr Sci 20(4):628-640. https://doi.org/10.1007/s11442-010-0628-5

Friedman George. 2017. There are 2 choke points that threaten oil trade between the Persian Gulf and East Asia. 18 April. http://www.businessinsider.com/maps-oil-trade-choke-points-person-gulf-and-east-asia-2017-4/?IR=T (last Accessed 09 Dec 2017)

Guo A. 2016. CNPC to start laying second China-Russia oil pipeline in June. 12 May

Guo S, Tang LC (2014) An intermodal analysis of major seaports in southern China, 11th international conference on service systems and service management (ICSSSM), 7. https://doi.org/10.1109/ICSSSM.2014.6874138 June

He K, Huo H, Zhang Q et al (2005) Oil consumption and CO $^{2}$ emissions in China's road transport: current status, future trends, and policy implications. Energy Policy 33:1499-1507

Kennedy A (2011) China's petroleum predicament: challenges and opportunities in Beijing's search for energy security. In: Golley J, Song L (eds) Rising China: global challenges and opportunities. Australian National University E-Press, Canberra, pp 121-135

Khanna P (2016) Connectography: Mapping the Future of Global Civilization. Random House.

Lee P.T-W, Hu Z-H, Lee S-J, Choi K-S, Shin S-H (2018) Research trends and agenda on the Belt and Road (B\&R) initiative with a focus on maritime transport. Maritime Policy \& Management 45(3):282-300

Liang J (2017) An analysis of strategic energy projects under the impact of OBOR initiative, with focus on key crude oil supply chain in China. In: Student Thesis supervised by Professor Tang LC in partial fulfillment of the requirements for the Degree of Bachelor of Engineering, National University of Singapore (NUS)

Liu C, Chen J, Sun X (2016) Location selection of China's oil import portfolio under the background of the belt and road initiative, Energy of China

National Bureau of Statistics of China. 2016. China Statistical Yearbook

National Development and Reform Commission. 2016. Support of Wuhan in building National Central city. http://www.sdpc. gov.cn/gzdt/201701/t20170125_836874.html (last accessed 09 Dec 2017)

National Development and Reform Commission, Ministry of Foreign Affairs, and Ministry of Commerce of the People's Republic of China, with State Council authorization. 2015. Vision and actions on jointly building silk road Economic Belt and 21st-century maritime silk road. March. http://en.ndrc.gov.cn/newsrelease/201503/t20150330_669367.html (last Accessed 09 Dec 2017)

Pan J, Wang L, Lou Y. 2016. Oil and natural gas resource potentials and its strategic selecting areas under the belt and road initiative, international petroleum Economics, 24, 10th ser., 13-16. September

Rimmer P, Lee P.T-W (2007) Repercussion of impeding shipping in the Malacca and Singapore Straits. Journal of International Logistics and Trade 5(1):7-26

Sandia National Laboratories (SNL). 2015. Energy infrastructure resilience. 29 April. https://energy.gov/sites/prod/files/2015/01/ f19/SNLResilienceApril29.pdf (last Accessed 09 Dec 2017)

Shaikh F, Ji Q, Fan Y (2016) Prospects of Pakistan-China energy and economic corridor. Renew Sust Energ Rev 59:253-263

Shenghong Petrochemical. 2016. Shenghong company profile. http://www.shenghongpec.com/guanyuwomen/ qiyegaikuang/ (last Accessed 21 Mar 2017)

Sheu JB, Kundu T (2017) Forecasting time-varying logistics distribution flows in the one belt-one road strategic context. Transp Res E. https://doi.org/10.1016/j.tre.2017.03.003 
Sinopec, Luoyang Petrochemical. 2015. http://www.sinopecgroup.com/group/Resource/Topic/kaifangri/lysh.html (last Accessed 21 Mar 2017)

Su L. 2013. Three inland crude oil sources for China. July 10. http://news.xinhuanet.com/globe/2013-07/17/c_132525854.htm (last Accessed Feb 15, 2017)

Wang LL, Zhao Y (2014) Analysis on China's importing petroleum transport channel safety and countermeasures. World Regional Studies 23(3):33-43

Xinhua Net. 2013. Refinery capacity will be over 600 million tons, industry rapid development. 24 July. http://news.xinhuanet. com/energy/2013-07/24/c_125053208_3.htm (last Accessed 19 Jan, 2017)

Xinhua Net. 2016. Observe top city structure from six central cities. 19 September. http://news.xinhuanet.com/city/2016-09/1 9/C_129285867_3.htm (last Accessed 21 Feb 2017)

Yang J, Liu Y, Li X et al (2017) Overview of wind power in China: status and future. Sustainability 9:1454

Yousafzai F. 2016. China to build mega oil pipeline from Gwadar to Kashgar. 13 June. http://nation.com.pk/national/13-Jun-2 016/china-to-buildmega-oil-pipeline-from-gwadar-to-kashgar(last Accessed 16 Feb 2017)

Zhang Z (2011) China's energy security, the Malacca dilemma and responses. Energy Policy 39:7612-7615

Zhao T. 2014. China oil products pipeline status and trends (2013). April 29. http://www.oilobserver.com/case/article/623 (last Accessed Dec 09, 2017)

\section{Publisher's Note}

Springer Nature remains neutral with regard to jurisdictional claims in published maps and institutional affiliations.

Submit your manuscript to a SpringerOpen ${ }^{\circ}$ journal and benefit from:

- Convenient online submission

- Rigorous peer review

- Open access: articles freely available online

- High visibility within the field

- Retaining the copyright to your article

Submit your next manuscript at $\boldsymbol{\nabla}$ springeropen.com 